\title{
Towards a Decentred History: The Study of the Holodomor and Ukrainian Historiography
}

\author{
Olga Andriewsky
}

Trent University

\begin{abstract}
This article reviews research on the Holodomor by historians of Ukraine since the late 1980s. It examines the dominant trends in historiography, the major findings, and the current state of the field. The field itself, it argues, has grown considerably and there now exists a critical body of scholarship on the subject. For the past two decades, this scholarship has largely been dominated by the debate about whether the Holodomor constitutes genocide. Much of the focus has been on illuminating the policies, methods, and intentions of the Soviet leadership and there have been notable advances in these areas of research. Social history on this topic, on the other hand, remains largely underdeveloped. Some historians of Ukraine have begun to study the Holodomor "from below" and to explore the larger social and cultural consequences of de-kulakization, collectivization, and the TerrorFamine. This approach is crucial, the author suggests, to understanding the exceptional nature of the era. In terms of patterns of migration, family structure, religious practices, social identity, status and ranking, and attitudes towards power, authority, and political participation, the Holodomor Era fundamentally changed the way Ukrainians lived. In this respect, it represents a turning point, as momentous as perhaps any in Ukrainian history.
\end{abstract}

Keywords: Famine, Ukrainian historiography, Genocide, Stalin

$\mathbf{L}$ ong before scholars in the Soviet Union and the West turned their attention to the subject of the Famine of 1932-33 in Ukraine, there was an audience anxious for the story to be told. Indeed, survivors in Canada and the United States, and elsewhere, did not simply wait passively for historians to begin studying what had happened to them in Ukraine under Stalin. They began recording their experiences decades before Robert Conquest's landmark study, Harvest of Sorrow, was published in 1986 (see also Suslyk; Solovey). In the 1950s, for example, a group of survivors in the diaspora published two volumes of memoirs and eyewitness accounts entitled The Black Deeds of the Kremlin (see Pidhainy). In fact, the Ukrainian diaspora played an active role not only in attempting to publicize the Holodomor but also in supporting research in North America, especially, the Harvard famine project of the 1980s, with which both Robert Conquest and James Mace were at one time associated (Sysyn 187-90). 
Similarly, in Ukraine, it was "pressure from below" that in the late 1980s broke more than a half-century of official silence on the subject. In 1988, as Stanislav Kul'chyts'kyi and others have noted, it was Ukrainian writers-Oleksii Musiienko, Ivan Drach, Borys Oliinyk, and Yurii Shcherbak-who first raised in public the issue of the famine and the deaths of millions of Ukrainians in the early 1930s (Kulchytsky, "Why Did Stalin"). (The writer and civic activist Ivan Drach is usually credited with popularizing the term "holodomor" - meaning "extermination by hunger"from moryty holodom.) Moreover, beginning in 1989, throughout Ukraine, in Poltava, Kharkiv, Kyiv, Vinnytsia, Zhytomyr, Dnipropetrovsk, and Luhansk oblasts, as the historian Oleksandra Veselova has described, memorials to the victims began to appear spontaneously in villages and towns, often in the form of crosses at the sites of known mass graves or at locations where churches had stood and were subsequently destroyed in the 1930s (Veselova, "Pam'iatni znaky"). By the summer of 1991, two journalists, Volodymyr Maniak and Lidiia Kovalenko, had published the first major book of interviews with survivors in Ukraine, "33-i Holod": Narodna knyha-Memorial (see Maniak and Kovalenko). The Holodomor, in this respect, has never been just an academic subject.

Indeed, as much as historians like to lament the politicization of scholarship on the subject, there has always been a political dimension to the study of the Holodomor. "Everything is political by the nature of things," Michel Foucault reminds us. "Everything is political by the existence of adversaries" (Foucault 390). From the half-century-long suppression of any public mention of the famine in the Soviet Union to the creation of the U.S. Commission on the Ukraine Famine under President Ronald Reagan in 1986, the study of the Holodomor has been enmeshed in a larger political discourse on the Soviet Union. It is a matter in which many different institutional and non-institutional actors have had and continue to have a vital stake. The interpretation of the Holodomor remains an especially contentious issue in relations between Russia and Ukraine. ${ }^{1}$

The peculiar dynamics of Holodomor Studies notwithstanding, the primary aim of this essay is to examine the research that has been done on the subject by historians of Ukraine over the course of the last three decades. What have historians of Ukraine learned about the Holodomor? What are the trends in Ukrainian historiography? How has our understanding of the Terror-Famine changed? How has our understanding

\footnotetext{
${ }^{1}$ As several U.S. State Department cables published in WikiLeaks attest, Russian diplomatic officials began actively working to "discourage" the international recognition of the Holodomor as genocide in 2008. See Zawada. See also Kul'chyts'kyi, "'Vynyshchuval'ni aktsii"; and Verstiuk.
} 
of Ukrainian history changed as a result?2 ${ }^{2}$ It is not my intention-it should be noted at the outset-to discuss popular conceptions and representations of the Holodomor. The politics of Holodomor commemoration are also not a main focus here. These are separate and complex topics that merit serious attention in their own right. ${ }^{3}$ I would, however, like to return-briefly-to the politics of Holodomor Studies in order to provide some context to understanding the course of research, research funding, and publication in recent years.

\section{The Politics of Holodomor StUdies: A FeW WordS}

There has been a profound transformation in the study of the Holodomor since the late 1980s. Perhaps, more accurately, it is the world in which the Holodomor is studied that has changed. The Soviet Union no longer exists. The archives in Ukraine and Russia became accessible in the late 1980s and early 1990s (though that trend has been to some degree reversed, particularly in Russia). The centre of research itself has moved from North America to Ukraine.

In the last decade, moreover, there has been a series of dramatic shifts in official policy and attitudes towards the Holodomor in Ukraine. Between 1991 and 2010, every president of Ukraine, beginning with Leonid Kravchuk, lent his support to the study of the Holodomor. Kravchuk was, in fact, the first president to refer to the Holodomor as genocide (Kravchuk 10). ${ }^{4}$ Under President Viktor Yushchenko, who came to power in 2005 in the wake of the pro-Western Orange Revolution, however, the public commemoration and study of the Holodomor became a major state project. (Yushchenko himself was born and grew up in a Ukrainian village in Sumy

\footnotetext{
2 By "Ukrainian historiography" I mean the work of professional historians who focus on the history of Ukraine, not the Soviet Union at large. To be sure, the boundaries between what constitutes Soviet history and Ukrainian history can be quite blurred and often overlap. The works of Hiroaki Kuromiya, Terry Martin, and Lynne Viola, for example, have much to say about Ukraine and the workings of the Soviet Union at large.

${ }^{3}$ The politics of Holodomor commemoration can, by now, be considered a subspecialty of the field. See, for example, Soldatenko, "Trahediia trydtsiat' tret'oho"; Himka; Viedienieiev and Budkov; Kas'ianov; Boryk; and Motyl.

${ }^{4}$ In 1993, at a conference in Kyiv on the 60th anniversary of the Holodomor Leonid Kravchuk, the first president of Ukraine in the post-Soviet era, remarked: "I agree completely that this was a planned action and that this was a genocide committed against the people. But we can't stop there. Yes, it was against the people, but it was directed from a different centre. That is how this horrendous page of our history should be treated."
} 
oblast-one of the hardest hit regions in Ukraine during the TerrorFamine.)

What was unusual after 2005 was the unprecedented scale of effort. Yushchenko launched an ambitious, nation-wide program of education, research and documentation, and commemoration. The fourth Saturday of November was designated by presidential decree as an official day of remembrance for "the victims of the Holodomors (sic)" (Ukaz Prezydenta Ukrainy № 431/2007). ${ }^{5}$ [Note the use of the plural here. The victims of the famines of 1921-22 and 1946-47 were included in the commemorations as well.] On 28 November 2006, the Parliament of Ukraine, with the president's support and in consultation with the National Academy of Sciences, voted to recognize the Ukrainian Famine of $1932-33$ as a deliberate act of genocide against the Ukrainian people ("Zakon Ukrainy pro Holodomor"). A vigorous international campaign was subsequently initiated by the Ministry of Foreign Affairs to have the United Nations, the Council of Europe, and other governments do the same.

Under Yushchenko, academic research and public education received considerable attention and unparalleled support. A museum in memory of the "Victims of the Holodomors" (Natsional'nyi muzei "Memorial pam'iati zhertv Holodomoriv $v$ Ukraini) was constructed in Kyiv for the $75^{\text {th }}$ anniversary in 2008. Built on a hill overlooking the Monastery of the Caves and the Dnipro River-one of the most sacred sites in all of Ukraine-the museum houses a permanent exhibit and a Hall of Memory (reminiscent of the Hall of Remembrance at the U.S. Holocaust Museum in Washington), where visitors can light a candle and ring a bell in memory of victims. To promote public awareness, the teaching of the Holodomor was introduced in schools throughout Ukraine, including post-secondary institutions and military schools. Provisions were made for the development of curricula and educational materials. National essay writing contests were organized for students at all levels of the school system ("Ukaz Prezydenta Ukrainy № $431 / 2007 ")$.

In 2006, as part of the project, the Ukrainian Institute of National Memory (Ukrains'kyi institut natsional'noi pam'iati) was established directly under Presidential administration. The mandate of the Institute was to conduct research and promote "the public memory of Ukrainian history with special attention to the twentieth century, the national liberation

\footnotetext{
${ }^{5}$ It was President Kuchma who in 1998 originally designated the fourth Saturday of November as a day to commemorate "the victims of the Holodomors (sic) and political repression” (“Ukaz Prezydenta Ukrainy № 1310/98”). Yushchenko, in 2007, assigned a separate day in May for the victims of political repression-thus elevating the symbolic significance of the Holodomor(s).
} 
struggles, and the victims of "the Holodomors" and political repression." In particular, the Institute was given the task of organizing a "National Book of Memory" (Natsional'na Knyha pam'iati) in preparation for the $75^{\text {th }}$ anniversary of the Terror-Famine in 2008. The National Book of Memory consists of nineteen volumes, a general volume as well as one volume for each of the seventeen oblasts/regions affected by the Holodomor. There is a separate volume on the city of Kyiv. Regional volumes were prepared by the respective oblast administration using a pre-determined template. Thus, each regional volume includes an introductory article by a local historian, documents relating to events in the region, eyewitness testimony, photographs, newspaper accounts as well as the names of Holodomor victims. To date, researchers have identified the names of some 882,510 victims of the Ukrainian Famine of 1932-33. ${ }^{6}$ President Yushchenko himself wrote the introduction to the main volume, referring to the Holodomor of 1932-33 as genocide, "the greatest tragedy in the history of the Ukrainian people" (vol. 1, 7). The National Book of Memory was a remarkably ambitious series completed in an astonishingly short period of time.

In general, under Yushchenko, research and publications on the Holodomor increased significantly. In 2007-2008, the high point of activity, over 250 academic books, articles, and collections of documents were published according to the former Director of the Institute of National Memory (Soldatenko "Trahediia" 9). The Yushchenko presidency was, in this respect, a "tipping point" in the study and popularization of the Holodomor. According to polling done in Ukraine in November 2013, 66\% of the population of Ukraine regarded the Holodomor as genocide and that percentage continues to rise (22\% rejected the idea, $12 \%$ had no opinion) ("Dvi tretyny"). ${ }^{7}$

In 2010, when Viktor Yanukovych, the leader of the pro-Russian Party of Regions, became president of Ukraine, the Holodomor was quickly demoted in terms of its official and symbolic importance (Motyl, "Deleting the Holodomor"). In April 2010, just as the Parliamentary Assembly of the

\footnotetext{
${ }^{6}$ There have been questions raised about the accuracy of the lists of victims. See Soldatenko, "Trahediia" 43-45. Given the time constraints that researchers were working under and the difficulty of recovering this kind of information many generations after the fact, errors and omissions would seem natural, indeed, inevitable.

7 There are of course, marked regional differences. Support was lowest in Crimea and the Donbas. What is often overlooked, however, is the rural/urban difference: $79 \%$ of the rural population is convinced that the Holodomor was genocide as compared to $60 \%$ of the urban population. See also "Kil'kist' ukraintsiv" and "Polovyna zhyteliv."
} 
Council of Europe was about to consider a resolution recognizing the Holodomor as genocide of the Ukrainian people (a Yushchenko initiative), President Yanukovych reversed Ukraine's official position. In Strasbourg, in an astonishing about-face, he declared, "We consider it incorrect and unjust to consider the Holodomor a fact of genocide of a certain people." It was, he said, "a common tragedy" of the Soviet people, claiming the lives of Russians, Belarusians, and Kazakhs as well as Ukrainians. "Those were the consequences of Stalin's totalitarian regime, his attitude to people," he said ("Yanukovych Reverses").

President Yanukovych's position on the Holodomor had immediate repercussions in academic circles. In July 2010, he appointed Valerii Soldatenko, a historian and member of the Communist Party of Ukraine, as head of the Institute of National Memory to replace Ihor Iukhnovs'kyi, the prominent physicist, parliamentarian, and a member of Yushchenko's party, Our Ukraine. In fact, the entire administration and staff of the Institute were eventually relieved of duties ("Iz Instituta Natspam'iati"). In one of his first public interviews, the newly appointed director explained his views on the Holodomor, echoing the point that Yanukovych had made at the Council of Europe that the 1932-1933 famine in Ukraine was "a terrible tragedy," "the result of difficult circumstances," but not deliberate. He also made clear that he prefers the term holod ("famine") rather than Holodomor ("Communist Ukrainian"). In response to Soldatenko's appointment, a group of prominent intellectuals, including several historians associated with the Institute of National Memory under Iukhnovs'kyi, created the "Public Committee to Honour the Memory of the Victims of the HolodomorGenocide" (Holodomor 1932-1933).

Under Soldatenko, the Institute of National Memory shifted its focus away from researching the Holodomor to other eras of Ukrainian history, most notably, the Cossack period and the Second World War. On the eightieth anniversary of the Famine in 2013, for example, the Institute of National Memory played a negligible role in marking the event. Perhaps most sensationally, the deputy director of the Institute, Dmytro Viedienieiev co-authored Zaruchnytsia hlobal'noho protystoiannia: Trahediia Velykoho Holodu 1932-1933 rr. v Ukraini v konteksti "kholodnoi viiny" (1945-1991 rr.) [Hostage of Global Confrontation: The Tragedy of the Great Famine of 1932-33 in Ukraine in the Context of the "Cold War"]. Tendentious and, in many ways, reminiscent of Soviet-era publications, the book argued that the Holodomor was a political project promoted by U.S. intelligence, American Sovietologists, and "Ukrainian nationalists" in the diaspora over the course of many decades-part of a deliberate campaign 
of psychological warfare waged against the Soviet Union. ${ }^{8}$ On 25 November 2013, the Institute sponsored a round-table discussion on this topic-the politics of memory-with the participation of Viedienieiev, the historian Heorhii Kas'ianov, and Viktor Voronin, an archivist (Soldatenko, "Ukrains'kyi instytut" 2). The study of the Holodomor, in line with Yanukovych's own position on the subject, was thus reduced in importance by the officially appointed keepers of "national memory."

Predictably, with the fall of Yanukovych, the Institute of National Memory has once again changed course. In March 2014, Volodymyr V'iatrovych, a thirty-seven-year-old historian, former director of the Archives of the Security Service of Ukraine, and member of the "Public Committee to Honour the Memory of the Victims of the HolodomorGenocide" was appointed as the new director of the Institute of National Memory ("Vitse-prem'ier"). V'iatrovych's views on the Terror-Famine are well known-he is an active proponent of the concept of the Holodomor as genocide. Whether research on the Holodomor once again becomes a national priority in its own right-with targeted funding-remains to be seen. Much depends, of course, on how events in Ukraine continue to unfold.

\section{WHAT HAVE WE LEARNED?}

Let us now return to our main questions-what have historians of Ukraine learned about the Holodomor? How has the scholarly work on the Ukrainian Famine done over the last 30 years added or changed their understanding? What are the trends in historiography?

Thirty years ago, it was possible to count the number of scholars working on some aspect of the Terror-Famine of 1932-33 on the fingers of one hand-Robert Conquest, James Mace, Roman Serbyn, Marco Carynnyk, and the demographer Sergei Maksudov. When, in 1983, Roman Serbyn organized a scholarly conference on the Famine of 1932-33 at the University of Montreal, it was a historic event in its own right. (The proceedings were subsequently published in 1986 by the Canadian Institute of Ukrainian Studies as Famine in Ukraine 1932-1933; see Serbyn and Krawchenko). After the publication of Robert Conquest's book in 1986,

\footnotetext{
8 The problem with this argument is that the Holodomor did not become part of the Cold War discourse in the U.S. until the mid-1980s and, even then, remained well on the margins of political and scholarly discussion. The authors appear unaware of what Frank Sysyn has called the great "inattention" of Western scholarship to this subject between the 1930s and 1980s. On the lack of interest in the Terror-Famine among Sovietologists and the intelligence community in the early years of the Cold War, see Andriewsky and Pringle.
} 
James Mace remained the only historian researching the famine in the United States. He first served as research assistant to Robert Conquest on Harvest of Sorrow while at the Harvard Ukrainian Research Institute. Then, in 1986 just as Conquest's book was going to print, he was appointed the Staff Director of the U.S. Commission on the Ukraine Famine in Washington.

James Mace was the first and, for a very long time, the only historian to go on record stating that the famine of 1932-33 in Ukraine constituted genocide (United States Commission xxiii). Not even Robert Conquest had gone quite that far. Without access to archival materials, without some knowledge of what was going on behind the scenes, few historians were willing to risk their credibility in making definitive pronouncements about the intentions of the Soviet leadership. ${ }^{9}$

Thirty years later, historians of Ukraine are no longer trying to convince their colleagues, as they were in the 1980s, that the death of millions of people in 1932-33 in Ukraine merits serious study. Today, there is a substantial cohort of professional historians engaged in original research, in exploring various aspects of the Holodomor. There is a large and growing list of publications. By some estimates, there are now over 20,000 publications relating to the Holodomor, the great majority of these appearing after the year 2000 (cf. the opening statements of the article by Stanislav Kul'chyts'kyi in this volume). We now have some 4,000-5,000 interviews with Holodomor survivors. Over 250 collections of documents have been assembled and published in Ukraine (Soldatenko, "Trahediia" 811; Botushans'ka). Archival collections have been catalogued and guides to these collections have been made public (Boriak and Papakin). There is, by now, a critical body of scholarship on the subject.

And even opponents of the concept of the Holodomor as genocide now concede that this has become the standard historical narrative in Ukraine (Soldatenko, "Trahediia" 4-8). The widespread use of the term Holodomor-rather than "famine"-is one sign of how much has changed. For most historians of Ukraine, and, indeed many non-historians, the word "famine" no longer seems adequate to describe what happened in Ukraine in 1932-33.10

\footnotetext{
${ }^{9}$ Much of the early research in Canada and the United States in the 1980s tended to concentrate on foreign diplomatic and press accounts of the famine, on what British and American journalists and diplomats knew, because these sources were accessible (See Carynnyk).

10 The changes in terminology are interesting. Conquest used "Terror-Famine"; the term "Ukrainian Holocaust" was popular among historians of Ukraine in North America in the 1980s and 1990s. But, as Kul'chyts'kyi (Ukrains'kyi Holodomor $v$ konteksti, 168) has argued, it is a misleading and inappropriate term that blurs the
} 
Indeed, in retrospect, it is remarkable how well James Mace's conclusions, stated in the U.S. Commission's Report to Congress in April 1988, have held up over time. Working with the official Soviet press and other published Soviet sources, with reports by Western journalists and diplomatic records, as well as with survivor accounts-but with no access to Soviet archives-he provided a remarkably cogent analysis. The Commission arrived at the following conclusions (vi-vii): ${ }^{11}$

1. There is no doubt that large numbers of inhabitants of the Ukrainian SSR and the North Caucasus Territory starved to death in a man-made famine in 1932-1933, caused by the seizure of the 1932 crop by Soviet authorities.

2. The victims of the Ukrainian Famine numbered in the millions.

3. Official Soviet allegations of "kulak sabotage," upon which all "difficulties" were blamed during the Famine, are false.

4. The Famine was not, as is often alleged, related to drought.

5. In 1931-1932, the official Soviet response to a drought-induced grain shortage outside Ukraine was to send aid to the areas affected and to make a series of concessions to the peasantry.

6. In mid-1932, following complaints by officials in the Ukrainian SSR that excessive grain procurements had led to localized outbreaks of famine, Moscow reversed course and took an increasingly hard line toward the peasantry.

7. The inability of Soviet authorities in Ukraine to meet the grain procurements quota forced them to introduce increasingly severe measures to extract the maximum quantity of grain from the peasants.

8. In the Fall of 1932 Stalin used the resulting "procurements crisis" in Ukraine as an excuse to tighten his control in Ukraine and to intensify grain seizures further.

9. The Ukrainian Famine of 1932-1933 was caused by the maximum extraction of agricultural produce from the rural population.

10. Officials in charge of grain seizures also lived in fear of punishment.

11. Stalin knew that people were starving to death in Ukraine by late 1932.

12. In January 1933, Stalin used the "laxity" of the Ukrainian authorities in seizing grain to strengthen further his control over the Communist Party of Ukraine and mandated actions that worsened the situation and maximized the loss of life.

lines between two altogether distinct events.

11 The last three points of the Executive Summary, which relate to U.S. foreign policy and Western scholarship, have been omitted here. 
13. Postyshev had a dual mandate from Moscow: to intensify the grain seizures (and therefore the Famine) in Ukraine and to eliminate such modest national self-assertion as Ukrainians had hitherto been allowed by the USSR.

14. While famine also took place during the 1932-1933 agricultural year in the Volga Basin and the North Caucasus Territory as a whole, the invasiveness of Stalin's interventions in both the Fall of 1932 and January 1933 in Ukraine are paralleled only in the ethnically Ukrainian Kuban region of the North Caucasus.

15. Attempts were made to prevent the starving from travelling to areas where food was more available.

16. Joseph Stalin and those around him committed genocide against Ukrainians in 1932-1933.

In many ways, Mace set the agenda for research on the Holodomor. The questions he raised regarding intentions, policy, and practice were subsequently taken up by an entire generation of historians of Ukraine. Stanislav Kul'chyts'kyi ("Dzheims Meis") has written movingly about his encounters-sometimes contentious-with Mace and the influence that Mace exercised on his own work and thinking in the early 1990s (See also Vasyl'iev, "Evoliutsiia"). This does not, in any way, diminish the tremendous amount of research that has been done by Kul'chyts'kyi and many other researchers over the last two decades. On the contrary, it is owing to them that Mace's findings remain relevant today. ${ }^{12}$ We now have a much more substantial and more refined picture of what happened in Ukraine in 19321933.

What have we learned? Here are some of the key discoveries and developments in recent years, using Mace's original findings as a reference. The list is by no means exhaustive.

\section{Demographic losses. How many people died as a result of the Holodomor in Ukraine?}

In 1988, in his Report to Congress, Mace was careful not to name an exact number, arguing that the available information was still too unreliable. He guessed at the time that the range was somewhere between 3 and 8

\footnotetext{
12 In the Report to Congress (xv), Mace, for example, concluded that Stalin knew that people were starving to death on the basis of a 1964 account published in Pravda by Roman Terekhov, who served as a member of the CP(b)U Politburo and Kharkiv regional secretary until late January 1933. Terekhov wrote that he personally told Stalin in December 1932 about the desperate situation in the villages of the Kharkiv region. Historians have now found many documents confirming Stalin's awareness of the famine.
} 
million. In the last decade, several teams of demographers, using increasingly sophisticated and complex methods, have attempted to estimate the losses incurred during the Holodomor. Historians and demographers are now beginning to settle on a range of 2.5 to 4.0 million excess deaths. An international team led by the French demographer Jacques Vallin estimated losses in 2002 at between 2.6 to 3.6 million people (Vallin et. al., 262). In 2008, the Institute for Demography and Social Studies of the National Academy of Sciences of Ukraine projected about 3.4-3.9 million excess deaths during the years 1932-34 (Wolowyna, "The FamineGenocide" 63; Libanova 29). As virtually every demographer and historian who has considered this question has noted, however, a precise figure cannot be established because of serious problems with Soviet census materials, especially the 1937 and 1939 data. The breakdown of recordkeeping in 1933, at the height of the famine, further complicates the issue (Wolowyna, "Holodomor Losses"; Shevchuk; Rudnyts'kyi and Savchuk).

It should be noted, moreover, that the number of excess deaths cited above does not capture the full extent of the demographic catastrophe-the drop in the birth rate, the fall in life expectancy, and the demographic trough created by the deaths of so many infants and children, for example. According to Kyiv demographers, lost births alone account for perhaps an additional one million (Wolowyna "Famine-Genocide" 62; Libanova "Otsinka" 276). ${ }^{13}$

Some of the most interesting research currently underway concerns regional variations in demographic losses (Levchuk, Wheatcroft, Rudnyts'kyi et. al.). ${ }^{14}$ (The National Book of Memory project served as an important stimulus in this regard.) Preliminary results suggest that population losses were highest in Kyiv and Kharkiv oblasts, and lowestexcluding the Moldavian Autonomous Republic - in Donetsk and Chernihiv (Levchuk 261). (Ukraine in 1932-33 consisted of seven oblasts: Vynnytsia, Dnipropetrovsk, Donetsk, Kyiv, Odesa, Kharkiv, Chernihiv and the Moldavian Autonomous Republic.) Without more research on migration patterns, resettlement policies and local history in the late 1920s and early

\footnotetext{
13 In 2009, the SBU (Security Service of Ukraine) estimated that Ukraine suffered a population loss of 10 million people- 3.9 million excess deaths and 6.1 million in lost births (Sukhomlin). The latter figure assumes that the exceptionally high fertility rate of the 1920s could have lasted until the 1930s. This assumption is rejected by Vallin, Wolowyna and others.

${ }^{14}$ The Harvard Ukrainian Research Institute has also launched a Geographic Information System (GIS) project aimed at creating a digital atlas of the Holodomor in Ukraine. See <http://gis.huri.harvard.edu/>
} 
1930s, however, it is far too early to arrive at any definitive conclusions about the meaning of these regional differences.

\section{Methods. How was the Holodomor implemented?}

We have learned much more about the specific measures and practices that were introduced in Ukraine and the Kuban in 1932-33, the mechanisms by which people were starved to death. As Michael Ellman (Ellman 680), the economic historian put it so clearly, the Holodomor was not simply an act of omission-failing to request or accept offers of relief from abroad. It was an act of commission. From impossibly high grain procurement quotas, to the decree of 20 November 1932 that halted the payment of grain to collective farm workers until their grain delivery quotas had been met, to the forcible removal of food from houses, there were special punitive measures that were introduced.

In particular, there has been substantial research on the practice of blacklisting villages, the so-called chorni doshky-a practice that was used widely in Ukraine and the Kuban in 1932-33. Heorhii Papakin, senior researcher at the Institute of History, Academy of Sciences of Ukraine, has been studying the subject for over a decade and has compiled a 180 pagelong list of villages and collective farms in Ukraine that were blacklisted ("Chorni doshky' iak oblychchia"). On the basis of his extensive work, it is fair to say that the practice of blacklisting villages was much more extensive and discriminatory than had previously been known (Papakin).

For a village to be blacklisted meant that 1) all stores would be closed and supplies removed from the village; 2) all trade was prohibited, including trade in food or grain; 3 ) all loans and advances were called in, including grain advances; 4) the local Party and collective farm organizations were purged, and usually subject to arrest; 5) food and livestock would be confiscated as a "penalty"; and 6) the territory would be sealed off by OGPU (secret police) detachments. In other words, residents had their supplies of food taken away and they were not allowed to leave. In effect, as Kul'chyts'kyi and others have argued, it was a death sentence imposed on the population (Kul'chyts'kyi "Holodomor 1932-33 rr.: Mekhanizm" 8; Papakin "Neopublikovani" 46).

The system of blacklisting was formalized by a Decree of 20 November 1932 titled, "The Struggle against Kurkul Influence in Collective Farms" [Pro borot'bu z kurkul's'kym vplyvom v kolhospakh]. As Papakin has pointed out, however, the target of the black lists were often not collective farms that had fallen behind in their grain deliveries or private farmers who failed to pay their tax in kind, but rather entire villages. That is, all of the inhabitants of a village were branded as kurkuls/kulaks and punished-even those who were not directly involved in the production of grain (blacksmiths, teachers, 
children etc.) ("Neopublikovani" 46-47). The quota was only one criterion; there were very few collective farms that were able to meet their assigned quota anywhere in Ukraine in the winter of 1932-33. The size of the village as well as its prominence in the region factored in the decision (from the internal correspondence it is clear that the practice of blacklisting villages was intended to serve as a warning for the surrounding population). ${ }^{15}$ The political past of the village, however, was also an important determinant. Villages with known supporters of the Ukrainian People's Republic in 1919 and/or with a history of resistance to Bolshevik grain requisitioning during the Civil War and collectivization were singled out. The entire village of Mazurivka in Vinnytsia oblast, for example, was blacklisted because it was the birthplace of one of Petliura's military commanders, Otaman Khmara (Papakin "'Chorni doshky' iak oblychchia" 4-6). On the basis of his extensive research, Papakin has concluded that the practice of blacklisting had a political as well as ethno-social dimension. For example, Cossack villages were a special target in the Volga region and, of course, in the Kuban. It was, in his words, a form of political retribution against those groups who had, in the past, demonstrated their opposition to the Soviet regime (Papkin 'Chorna doshka': Antyselians'ki 338).

According to Papakin, there were blacklisted villages in all of the oblasts of Ukraine, and in some districts/raions, virtually every settlement was included. In Vinnytsia, there were five entire raions that were blacklisted; in Dnipropetrovsk, every single raion had blacklisted villages (Papakin “'Chorni doshky' v Ukraini: mekhanizm" 6-7, 13). Papakin believes, on the basis of preliminary research, that there is a strong correlation between blacklisting and mortality - but, as he himself admits, this requires further study (Papakin "Chorni doshky' iak oblychchia" 7).16

The other major revelation was the discovery of the existence of a formal decree prohibiting peasants in Ukraine and the Kuban from leaving starvation-hit areas in search of food in neighbouring regions of the Soviet Union. The secret directive issued in Moscow on 22 January 1933 was simply entitled, "Preventing the Mass Exodus of Peasants who are Starving" (Dyrektyva TsK VKP(b) i RNK SRSR "Pro zapobihannia masovoho vyizdu

\footnotetext{
15 According to Papakin, settlements were chosen by local raion Party committees that were under great pressure from "above," from Kosior and Chubar and especially Kaganovich. Kaganovich also supported the idea of economic blockades of the raions that were farthest behind in delivering grain.

16 Stephen Wheatcroft (219-25) recently challenged the notion that there was a correlation between blacklisting villages and mortality based on raion (district) data. Without reliable data and local history at the village level, however, it is premature to dismiss the significance or outcomes of "blacklisting."
} 
selian, iaki holoduiut "' vid 22 sichnia $1933 \mathrm{r}$.). It prohibited the sale of tickets for transport by train or boat to peasants. In effect, the borders of Soviet Ukraine and the Kuban were closed by the secret police and militia detachments. In the six weeks after the decree was issued, nearly 220,000 people were arrested, an astonishingly high number (Danilov 3: 634-35; Pyrih 609-16; Ivnitskii 204).

Mace had concluded on the basis of anecdotal evidence that this was, in fact, the policy. Now, as we know, it was a formal order signed by Stalin himself. This is what the historian Roman Serbyn has called the "smoking gun." The directive, he concluded is "perhaps the best available proof of the dictator's genocidal intent against the Ukrainian nation" (Serbyn "Smoking Gun").

Finally, new studies have revealed the very selective-indeed, highly politicized-nature of state assistance in Ukraine in 1932-1933. Soviet authorities, as we know, took great pains to guarantee the supply of food to the industrial workforce and to certain other categories of the populationRed Army personnel and their families, for example. As the latest research has shown, however, in the spring of 1933, famine relief itself became an ideological instrument. The aid that was provided in rural Ukraine at the height of the Famine, when much of the population was starving, was directed, first and foremost, to "conscientious" collective farm workersthose who had worked the highest number of workdays. Rations, as the sources attest, were allocated in connection with spring sowing (T. Boriak 18-21; Werth). ${ }^{17}$ The bulk of assistance was delivered in the form of grain seed that was "lent" to collective farms (from reserves that had been seized in Ukraine) with the stipulation that it would be repaid with interest (T. Boriak 15-16). State aid, it seems clear, was aimed at trying to salvage the collective farm system and a workforce necessary to maintain it. At the very same time, Party officials announced a campaign to root out "enemy elements of all kinds who sought to exploit the food problems for their own counter-revolutionary purposes, spreading rumours about the famine and various 'horrors"' (Werth, fn 25: Vasyl'iev, "Porivnial'nyi analiz" 127). Famine-relief, in this way, became yet another way to determine who lived and who died.

\section{Stalin. What have we learned about Stalin and his intentions?}

The question of intentions has always been at heart of the discussion of the Holodomor. In his report to Congress, James Mace concluded-again, on the basis of anecdotal evidence-that "Stalin knew that people were

17 This stands in sharp contrast to 1932, when famine relief was distributed, generally, in famine-stricken areas through canteens. 
starving to death in Ukraine by late 1932." Historians of Ukraine have been keenly interested in this problem for a very long time: What did the Kremlin know, when did they know it, and how did they respond to the information they had? A number of scholars, including Stanislav Kul'chyts'kyi, Mykola Doroshko, Iurii Shapoval, and Valerii Vasyl'iev, have written extensively on relations between the Kremlin and the leadership of the Ukrainian Communist Party. ${ }^{18}$ The relationship between Kharkiv and local Party organizations has also been a subject of interest. In part, this is a response to suggestions by some historians that the particular viciousness and lethalness of the Famine-Terror in Ukraine may have been a reflection of the way that local leaders interpreted policy rather than the policies and measures themselves (Vasyl'iev, "Osoblyvosti" 1). The publication in 2008 of Holodomor 1932-33 rokiv v Ukraini: dokumenty i materialy-a 1,125-page collection of Russian and Ukrainian archival documents relating to the Holodomor under the auspices of the Institute of History of the Academy of Sciences of Ukraine-has, in addition, greatly advanced our understanding in these areas (Pyrih).

This research put to rest, once and for all, any notion that Stalin and his circle might have been unaware of how grave the situation in Ukraine was in 1932 and 1933. Ukraine was in crisis by the winter of 1931-32, as numerous letters and documents attest. There was evidence of famine, people were starving to death, there were reports of cannibalism, some were beginning to flee the village, popular opposition was growing, farmers were slaughtering livestock, armed grain collection brigades were roaming the countryside, violence was mounting, the agricultural sector appeared to be collapsing, there was unrest in the Party, and, in some areas, Soviet authority itself was breaking down. There was genuine concern in Kharkiv as to whether the peasants would even have the capacity to undertake another growing season. Several Ukrainian Communist Party leaders, most notably Vlas Chubar, the Chairman of the Ukrainian Council of People's Commissars (Radnarkom; Russ: Sovnarkom), and Hryhorii Petrovs'kyi, Chairman of the Central Executive Committee of the Soviet Union, made repeated efforts, beginning in March 1932, to alert Stalin and the Politburo and to seek some form of relief-even as they continued to execute their orders (Kul'chyts'kyi, Ukrains'kyi Holodomor v konteksti, ch. 5). The letters that Chubar and Petrovs'kyi wrote to the Kremlin on 10 June-cited widely by scholars-are merely part of an ongoing exchange between Kharkiv and Moscow about the situation in Ukraine (Davies et al 167-70, 180-81). Stalin, as we now know, was very much a "hands-on" leader, intimately involved in

18 Cf. Vasyl'ev, "Osoblyvosti"; Vasyl'ev and Shapoval; Doroshko; Kul'chyts'kyi, Ukrains'kyi Holodomor v konteksti, and his "Stalins'ka dyktatura." 
the details of administration. He himself expressed concern on numerous occasions, most notably in a letter to Lazar Kaganovich on 11 August 1932: "At this point the question of Ukraine is the most important. The situation in Ukraine is terrible. If we don't take steps now to improve the situation, we may lose Ukraine" (Davies et al 180).

Stalin responded to the crisis in a manner that we now know was typical-he blamed the "Ukrainians" (his words), Chubar and Kosior, and others-for the failures. And his solution, ultimately, was to intensify the use of force and repression. "The Soviet leadership understood that catastrophe was looming," Valerii Vasyl'iev wrote in his study of the Soviet leadership. "Molotov, upon returning from Ukraine [in the summer of 1932], admitted at a meeting of the Politburo that 'We are on the verge of famine in many of the grain-growing districts."' The Politburo, however, decided to "go ahead with the grain procurement plan at all costs" (Vasyl'iev, "Osoblyvosti" 5; Ivnitskii Golod 355).

What this research has revealed, quite clearly, is the "Ukrainian vector" of the Famine-the political dimension of Stalin's thinking and the special fixation he had on Ukraine. It was, in his own words, "a distinctive republic". "The most important issue right now is Ukraine", he emphasized in his correspondence. By Stalin's own admission, the campaign of 1932-33 in Ukraine was not just about grain. It was part of a larger political battle for Ukraine, a fight against what he deemed "counter-revolution" (Davies et. al. 180-81). Stalin himself, we now know, was under threat from critics within the Party. The battle for Ukraine thus became, as Stanislav Kul'chyts'kyi has argued, part of Stalin's own struggle against those who blamed him for the disasters of collectivization (Kul'chyts'kyi Ukrains'kyi Holodomor v konteksti 102-103). Ukrainian Communists, in particular, were not to be trusted. The Party, Stalin believed, was full of "rotten elements, conscious and instinctive adherents of Petliura, and direct agents of Piłsudski." For Stalin, as Lars Lih, one of the editors of the Stalin-Molotov correspondence, has observed, governing was an "eternal battle" with "saboteurs" (Lih et. al. 17). In the early fall of 1932, the Kremlin prepared for a decisive battle, mobilizing the Party, military, and the secret service for the campaign. Each grain collection brigade was to be escorted by military units as well as shock brigades of militant Communists. It was, in effect, a counter-insurgency launched against an unarmed civilian population. As Ukraine began once again to fall behind in its grain deliveries, Stalin sent his most trusted lieutenants, first Molotov then Postyshev, to oversee the operation, to purge the Party of unreliable elements, and, ultimately, to deliver the "shattering blow" (sokrushitel'nyi udar), as Stalin put it. The "shattering blow," Kul'chyts'kyi has argued, was the instruction on 18 November 1932, to conduct house-to-house searches for "stolen grain" and to permit the 
confiscation of all food, including meat and potatoes, as a penalty (Kul'chyts'kyi, Ukrains'kyi Holodomor v konteksti 102-103). ${ }^{19}$

What is now also clear is the direct connection in Stalin's mind between the difficulties of grain procurement and the policy of Ukrainization. This is something that historians who do not study Ukraine often ignore. The incorrect policy of Ukrainization, Stalin claimed, had given legal cover to all manner of "bourgeois nationalists," "Petliurites" and kulaks (Ukrainian: kurkuls) who were based in the countryside, and who had "infiltrated" the collective farms as "administrators, accountants, warehouse supervisors, millers, members of village soviets, and cooperatives." They were now actively working to organize a counter-revolution and to sabotage the collection of grain. On 14 December 1932, he signed a decree ordering the arrests of these counter-revolutionaries, the expulsion of the "Petliurites and other bourgeois nationalist elements" from the Party and all Soviet institutions, and the closing down of all Ukrainian newspapers and journals. In the Kuban, it brought an end to Ukrainian language education as well (Pyrih 475-77).

The struggle against "counter-revolutionary" elements thus served as a pretext for a massive purge of the Communist Party of Ukraine and collective farm administrations (fifty percent of collective farm chairs and their assistants), as well as the arrest of tens of thousands of people. (Some 125,000 people were arrested in 1933.) Thousands were sent to concentration camps. Hundreds of Ukrainian intellectuals were expelled from their research institutions, especially those associated in some way with Mykola Skrypnyk, the Commissar of Education in Ukraine and a leading proponent of Ukrainization. Entire institutions like the Bahalii Research Institute of History and Culture and the Ukrainian Soviet Encyclopedia were eventually closed down. “1933," Pavel Postyshev later declared, was "the year of the defeat of Ukrainian nationalist counterrevolution" (Postyshev 165). ${ }^{20}$

\footnotetext{
19 Stalin used the term "shattering blow" at a meeting of the Politburo and Presidium of the Central Committee of the Party on 27 November 1932 while defending himself against allegations that he was responsible for the failure of the grain procurement campaign. He blamed the failures on anti-Soviet elements ("Petliurites") who had infiltrated the collective farms and local Communist Party officials. The only correct response, he argued, was to deliver the "shattering blow". 20 On the arrests and the campaign against Ukrainization, see Vasyl'ev, "Osoblyvosti"; Danylenko and Bondarchuk; Kocherha; Iefimenko.
} 


\section{Was it genocide?}

The emergence of Genocide Studies as a distinct academic field since the late 1990s has exerted a powerful influence on the study of the Holodomor. In particular, the rediscovery, or rather discovery, of Rafael Lemkin, the originator of the concept of genocide, the spirit behind the U.N. Convention on the Prevention and Punishment of the Crime of Genocide, and the pioneer of Genocide Studies, has excited many scholars of the Holodomor (Antonovych; Serbyn, "Ukrainian Famine"; Klid and Motyl). Lemkin's notion of genocide, which he began to develop in the interwar period, was intrinsically linked to colonialism and the practices of settlement and occupation. It is precisely this broad approach that has proven so attractive to historians of Ukraine-Lemkin's view of genocide as a complex process with many forms, including political, economic, and cultural coercion, and not just physical violence. Genocide, in this respect, did "not necessarily mean immediate destruction" but, rather, targeting the institutions, culture and the economic existence of a group (Lemkin Axis Rule 79).

Ukraine, as researchers have discovered, was crucial to Lemkin's thinking about genocide. This he made clear in a previously unpublished essay written in 1953, i.e., on the twentieth anniversary of the Holodomor. It was intended as a chapter of a larger book entitled History of Genocide. In this essay, Lemkin argued that Ukraine was a "classical example of Soviet genocide, its longest and broadest experiment in Russification-the destruction of the Ukrainian nation" (Lemkin, "Soviet Genocide" 235-42) The Holodomor (he, of course, did not use this word) was merely one episode of this extended process. The repeated attacks on Ukrainian intellectuals, the assault on religion and the Ukrainian churches, the dispersal and fragmentation of the Ukrainian people-all of these were part of a larger pattern. "The genocide was not that Stalin's regime killed so many people," as one Lemkin scholar explained, "but that these individuals were killed with the purpose of destroying the Ukrainian way of life" (IrvinErickson 68).

For historians of Ukraine, the emergence of Genocide Studies and the rediscovery of Rafael Lemkin have helped to reframe the problem of "intentions" and have greatly expanded the discussion of what constitutes genocide. ${ }^{21}$ Like Lemkin, many scholars have come to view the Holodomor as merely one episode in a much longer and more complex history of coercion, suppression, and violence aimed at the destruction of Ukrainians

\footnotetext{
${ }^{21}$ Among legal scholars, there has been a vigorous discussion and reappraisal of "intent" as it applies to the definition of genocide, especially since the creation of the International Criminal Court. Cf. Ambos, Greenawalt.
} 
as a people, a history they believe began well before 1932-33 and continued well beyond it. ${ }^{22}$ In this respect, the link between colonialism and genocide-a link emphasized by genocide scholars like A. Dirk Moses and promoted most recently by the historian Mark von Hagen-has opened up new ways to conceptualize the genocidal nature of the Holodomor (von Hagen; McDonnell and Moses).

Other historians of Ukraine, in making the argument for genocide, continue to accentuate the uniquely lethal and punitive aspects of the Holodomor. ${ }^{23}$ The numbers in themselves, they stress, are astounding, unprecedented in European history, much less the history of Ukraine. Ukraine lost a substantial part of its population in a matter of a few months in 1933 (February-July) (Volovyna). It was not, moreover, simply a matter of "bungling" or "indifference." These staggering losses were the result of decisions taken in the winter of 1932-33, decisions that "wilfully" maximized the losses in Ukraine and in the Kuban. Here, as Andrea Graziosi notes, the "scale of both punishment and terror reached extreme dimensions... thus growing into a qualitatively different phenomenon" ("Soviet Famines" 108). During the Holodomor, as millions of people were dying, the authorities waged a war against "Ukrainian nationalism." The attack on the Ukrainian countryside, in conjunction with the large-scale assault on the Ukrainian church, and Ukrainian rural and urban elites, were an attempt to crush Ukrainians, these historians argue, and thus constitute an act of genocide by the terms of the U.N. Convention.

\section{Contested History}

Of course, not all historians of Ukraine have been persuaded by the genocide argument. Most notably, Valerii Soldatenko, the former Director of the Institute of National Memory, rejected the application of the concept of genocide to events in Ukraine in 1932-33, while at the same time deploring the "politicization" of the issue (Soldatenko, "Trahediia" 4-8). ${ }^{24}$ For him, as for other like-minded historians, the problem turns on the issue of intentions. "There is not a single document that supports the concept of the

\footnotetext{
22 The notion of three "Holodomors" (1921-1923, 1932-1933, 1946-1947) is one expression of this interpretation. Cf. Antonovych; Veselova "Holod"; Veselova and Marochko; and Odynoka.

${ }^{23}$ Cf. Kul'chyts'kyi, Shapoval, Vasyl'iev, Verstiuk, Graziosi, Vasylenko, Werth. Of course, the two approaches to understanding the Holodomor as genocide are not mutually exclusive.

${ }^{24}$ Soldatenko treated H. Kas'ianov, V. Kharchenko, and D. Viedienieiev as historians of Ukraine.
} 
Holodomor as genocide in Ukraine or that even hints at ethnic motives" ("Trahediia" 20).

What happened in Ukraine in 1932-33 must be understood in a larger geopolitical context-the threat of war and the urgent need to industrialize in preparation for it. The aim of collectivization, first and foremost, according to this view, was the mobilization of resources for industrialization and the reorganization and modernization of the agricultural economy. Overcoming the resistance of the peasantry, however, was a necessary part of this process. As Soldatenko acknowledges, "these policies resulted in the massive disorganization of the agrarian sector of the economy and they were carried out, in some cases, with extreme violence against the peasant population. (He recognizes that the economic policies were a failure in the short term.) The famine was not a uniquely Ukrainian experience but rather a "common tragedy shared by all the people of the former Soviet Union," Soldatenko has concluded, echoing the argument made by Russian historians. As evidence of this, he cites the higher death rates in the North Caucasus, Kazakhstan, and in the Volga German Republic ("Trahediia" 22; "Prychyny").

What is significant here-and a measure of how much the understanding of the Holodomor has changed-is the very narrowness of the debate that Soldatenko describes. Even the opponents of the concept of the Holodomor as genocide accept the basic outlines of what happened. Among historians, there is no significant argument over the number of people who died. There is a general agreement that they died as a result of the policies implemented by the Party leadership, the introduction of unrealistically high grain quotas, and the confiscation of grain resources and food. Historians of Ukraine are no longer debating whether the Famine was the result of natural causes. The academic debate appears to come down to the issue of intentions, to whether the special measures undertaken in Ukraine in the winter of 1932-33 that intensified starvation were aimed at Ukrainians as such. For Soldatenko, however, the debate is really about the significance of what happened-no small issue, by any means. For him and others, the Holodomor was the tragic price-a terribly steep but ultimately justifiable price—that was paid for "modernization."

\section{Decentring History}

Curiously, what has largely been missing from the academic literature until recently are Ukrainians themselves - the millions of ordinary men and women who experienced de-kulakization, collectivization, and the Holodomor. That may seem like a preposterous statement in light of the enormous efforts that have been made to collect and publish eyewitness testimonies, to identify and inscribe the names of people who died during 
the Holodomor, and to create a "national memory." Many oral history projects have been undertaken in the last twenty years, most notably, of course, The National Book of Memory (Natsional'na Knyha pam'iati) project in which thousands of local historians, archival workers, teachers and students participated.

Yet we still know relatively little about the lives of these people beyond the names. Among historians of Ukraine, much of the focus of research has been on "seeing like a state," to use the James C. Scott's celebrated phrase. ${ }^{25}$ Much of the work has emphasized the intentions, policy, and methods of the Soviet leadership, much of the story has been about Stalin and Molotov, Kaganovich and Kosior and Chubar-and what they thought, how they spoke, and what they did. ${ }^{26}$ One of the-no doubt unintendedconsequences of the genocide debate that has dominated scholarship for nearly twenty years is that it tended to marginalize the people who experienced the Holodomor, rendering them into ghosts who silently haunt our work. ${ }^{27}$ Their accounts as yet remain distant from the academic literature, summoned-if summoned at all-mainly as witnesses to the terrible deeds committed by "others." What we lack, for the most part, is a rich, full-blooded, detailed "history from below."

This observation is not intended to disparage the efforts of those scholars who work on Soviet policy and intentions. Nor is it meant to discount the work of all of those many, many individuals who have collected oral histories of the Holodomor. This kind of research is vitally necessary and important-in ways that go well beyond scholarship. Indeed, one of the hidden casualties of the Holodomor was social memory itself. After 1932-33, the Ukrainian village lost much of its autonomous capacity to tell stories, to relate its own collective history, to construct its own portrait of itself. In this respect, oral history is a way of restoring that capacity, of rebuilding collective memory and identity, perhaps even a way of healing what James Mace called a "post-genocidal society." The very act of consulting elderly rural residents-often women, the most impoverished

25 Though he does not discuss the Terror-Famine, Scott does write about Soviet collectivization as a notable example of high modernist ideology (see Scott).

26 The need to understand the intentions of the Soviet authorities was also keenly felt among survivors. In his memoirs, Miron Dolot, a famine survivor and author of a rare full-length personal account of the Holodomor, could not resist interpreting the motives and intentions of the authorities (see Dolot).

27 Increasingly, because they provide a glimpse of local practice, eyewitness accounts have become important in corroborating, expanding on and, in some cases, contradicting official documents (see Veselova, "Svidchennia ochevydtsiv"). 
and neglected segment of the population-is in itself a powerfully transformative exercise.

There is a crucial difference, however, between collecting oral history and critically analyzing testimonies, between gathering evidence and relating that evidence to larger social and cultural patterns, between publishing eyewitness accounts and writing social history. And when it comes to Holodomor, there is still a very long way to go. Social history remains, without doubt, a largely unexplored frontier. ${ }^{28}$

Perhaps the first real glimpse into the momentous possibilities of a decentred history-and of the very significance of this approach-was the research done in the 1990s by Andrea Graziosi (The Great Soviet Peasant War), Lynne Viola (Peasant Rebels under Stalin Collectivization and the Culture of Peasant Resistance), and Liudmyla Hrynevych ("Stalins'ka 'Revoliutsiia zhory'") on resistance to state policies in Ukraine between 1928 and $1933 .{ }^{29}$ Ukraine, during collectivization, as Lynne Viola noted in her book, "led [the Soviet Union] in revolt." The revolts in Ukraine tended to be frequent, large, and occasionally violent, especially during periods of grain requisitioning. In 1930, at the height of resistance, according to OGPU sources, the participants numbered close to a million. "Throughout Ukraine," as Viola describes, "peasants rose up in defense of their property, neighbours, and culture, displaying a sense of political and national outrage and purpose unparalleled in the [Soviet Union]" (Viola 158-59). Liudmyla Hrynevych's work picks up where Viola's left off, and provides a fuller picture of the nature of these protests, the degree to which they became more organized and overtly anti-Soviet and anti-colonial during this period.

The real breakthrough of this work was in their approach, in their foregrounding of previously marginalized actors. They were histories of ordinary people, how they thought, how they behaved, and how they attempted to survive under extraordinary circumstances. It was a history that exposed the uneven character of Soviet power. Collectivization, as Viola explained, was not just an economic policy, it was a "clash of cultures," "a wholesale assault on the cultural traditions and institutions of the village," most notably the church. This is how the peasants understood it, as "a battle over their culture and way of life, as pillage, injustice and wrong." It was a "struggle for power and control," an attempt to subjugate them (Viola 14).

${ }^{28}$ Liudmyla Hrynevych's magnum opus, Khronika kolektyvizatsii ta Holodomoru $v$ Ukraini 1927-1933, is the most ambitious attempt to fill this gap. As of this writing, the first volume of four has been published.

29 Though not as well known, the early research by Valerii Vasil'ev cited by Viola in her own book should be added to this list. 
And the Holodomor, if we take Viola's argument to its logical conclusion, was the climax of this life-and-death struggle.

This theme-the Holodomor Era as a "cultural war"-has begun to receive greater attention among scholars of Ukraine in recent years and represents a crucial trend in the scholarship. In particular, it is ethnographers in Ukraine who have led the way in attempting to assess the cultural impact of collectivization, de-kulakization, and the Terror-Famine. It is ethnographers who have also-not surprisingly-made the greatest use of eyewitness accounts. William Noll, an American ethnomusicologist, and his team of Ukrainian researchers, did the pioneering work in this field. Between 1993 and 1995, they conducted interviews with 450 elderly rural residents in eastern and southern Ukraine in an attempt to understand how village life changed in the 1920s and 1930s. As described in their bookTransformatsiia hromadians'koho suspil'stva. Usna istoriia selians'koi kul'tury 1920-30 rokiv [The Transformation of Civil Society: An Oral History of Peasant Culture in the 1920s and 1930s] - the Holodomor era not only resulted in the deaths of millions of people. It radically changed the Ukrainian village; it led to the material impoverishment of the peasantry. It did away with entire categories of craftsmen, village residents and artists (icon painters, fiddlers, and other itinerant musical performers like the blind startsi). And, ultimately, it led to the decline, indeed destruction, of many traditional practices and institutions. Cultural practices associated with the church and religious holidays were special targets-not just baptisms, church weddings, and church funerals which were central events in the life of country folk, but also koliadky (Christmas carols) and vesnianky (spring songs).

Indeed, as Noll and his colleagues discovered, the very tenor of everyday life was transformed during the Holodomor era. Even the seemingly innocent traditional practices like the dosvitky-the ritual gatherings of young unmarried women who met every evening in the winter to sew and embroider and sing-were suppressed. Village clubs, organized and managed by Party officials, replaced them. In the final analysis, Noll argued, collectivization, de-kulakization, and the TerrorFamine were a "cultural catastrophe."

More recently, Olesia Stasiuk published a bold new study of the Ukrainian village during the Holodomor era entitled Henotsyd ukraintsiv: deformatsiia narodnoi kul'tury (Genocide of Ukrainians: The Deformation of National Culture). In contrast to Noll, Stasiuk was interested in the larger social consequences of collectivization and the Terror-Famine, in the way in which individuals and families were affected. In often harrowing terms, she describes the violence with which the policy of collectivization and grain requisitioning was often implemented-how ordinary people were 
humiliated, ostracized, and terrorized. She discusses the mass flight from the countryside and the breakdown and destruction of the family. But Stasiuk was also interested in the effects of the Holodomor on social mores: the rise of the culture of denunciations (donosy), the increase in petty theft. Henotsyd ukraintsiv, perhaps more than any other academic work to date, illustrates what it meant to live through the Holodomor.

Regional and local histories represent another promising trend in Ukrainian historiography. A number of studies have been produced in recent years focusing on the Holodomor at the oblast and even village level. ${ }^{30}$ (The National Book of Memory series, with seventeen separate regional volumes provided an important stimulus to research in this area.) The value of this approach, it goes without saying, is in illuminating how policy and directives were put into practice and how, on the other hand, various groups and individuals, including local Party officials, responded to the severe challenges posed by the Holodomor. Ultimately, such histories will also help to shed light on regional variations, including differences in population losses already noted by demographers. At present, however, this area of research remains at a very early stage in its development, the results are quite uneven, and scholars are not yet in any position to offer a meaningful comparative analysis.

Indeed, there are many gaps in the historiography. There is still no systematic study of the strategies that people used to try to survive the Holodomor. Not much is known about the other victims of the Holodomor-those hundreds of thousands of people who were arrested and/or exiled in 1932-33. The actual history and fate of blacklisted villages remain unexplored. There is very little scholarship on gender-Oksana Kis's ground-breaking work on women constitutes a notable exception (see Kis). Little has been written on the urban experience. ${ }^{31}$ And, of course, there is no serious study of the "perpetrators," i.e., those who carried out orders in the Ukrainian countryside and who, in some cases, themselves became victims. ${ }^{32}$ In this respect, Holodomor Studies is still a very new field of research.

\footnotetext{
${ }^{30}$ See Iatsenko; Starovoitov and Mykhailychenko; Akunin; Matvieiev; Pshenychnyi; Bakhtin.

31 The exceptions here are the work of Borysenko and Kuromiya.

32 The recent publication of documents relating to local Party activists in Ukraine by Vasyl'iev et. al. (Partiino-radians'ke kerivnytstvo) is an important step and should facilitate further scholarship on the subject.
} 


\section{The Impact on Ukrainian History: A Final Thought}

Finally, let us consider our last question-what impact has the study of the Holodomor had on our understanding of Ukrainian history? There is no single answer to this question. For many historians of Ukraine, the significance of the Holodomor is measured in terms of the number of lives lost, in the size and scale of the demographic catastrophe. For Soldatenko and like-minded colleagues, the Holodomor was a terrible but necessary price to be paid for industrialization and modernization. For others, the Holodomor represents the darkest chapter in a whole series of violent assaults on the Ukrainian people perpetrated by a totalitarian state. The discussion, in many ways, continues to revolve around the Soviet paradigm.

As someone who comes to the subject from the nineteenth centuryfrom the study of Ukraine before the Soviet Union-I would like to suggest a different way of thinking about this problem. Viewed in a larger context, the Holodomor Era-and here I would include de-kulakization, collectivization and the Terror-Famine-represents a considerable rupture in the history of Ukraine. In terms of patterns of migration, family structure, religious practices, rituals of courtship and marriage, names and naming practices, in terms of status and ranking, in terms of attitudes towards power, authority, and political participation, in terms of social identity, this period constitutes a radical break. The Holodomor Era fundamentally changed the way Ukrainians (and others) lived.

The Holodomor also marks the violent end of a particular social order: the end of a set of social structures, social institutions and social practices associated with Cossack history and culture in Ukraine. It was a social order that had endured, with significant changes, of course, since the seventeenth century and that had come to be seen as manifestly Ukrainian. Long after the end of the Hetmanate, the destruction of the Sich, the incorporation of the officer class into the Russian nobility, and the expansion of serfdom, there were still ordinary Cossacks and Cossack settlements throughout "Malorossiia." 33 In Poltava and in large parts of Chernihiv gubernia at the beginning of the twentieth century, they represented nearly fifty percent of the population (Bachyns'ka 24). Here, in rural Ukraine, Cossack status served, in effect, as the line between freedom and bondage. The Cossacks remained a distinct group with distinct property rights and a distinct legal status until the twentieth century-a group, moreover, who consciously cultivated Cossack history and identity as an expression of their social

\footnotetext{
${ }^{33}$ Here I am referring to the descendants of the "registered Cossacks." Until the 1860s, Ukrainian Cossacks from "Malorossia" served as a reserve guard to be called up in case of war. They were also instrumental in the colonization of southern Ukraine and the Kuban (Bachyns'ka; Petrenko).
} 
standing. ${ }^{34}$ The Revolution of 1917 , as we know, reanimated the Cossack movement, especially on the territory of the former Hetmanate, and, ultimately, put it on a collision course with Soviet authorities.

The Holodomor era was the final chapter in this confrontation. It deprived the population of their land, the very foundation of their social organization. It erased their social identity, transforming and reducing a diverse rural population into "kulaks" and "peasants." It extinguished the last remnants of village autonomy. It destroyed a substantial part of the material culture. It devastated one of the vital seedbeds of the Ukrainian national movement. It eliminated, once and for all, the social basis of a very formidable political opponent. And, of course, the Holodomor destroyed many, many lives.

In this respect, I would argue, the era of the Holodomor was exceptional and represents a turning point, as momentous as perhaps any in Ukrainian history. The human losses were staggering, the social and cultural, not to mention psychological, consequences of de-kulakization, collectivization, and the Terror-Famine were profound. The Holodomor should not, for this reason, be conflated with other famines in Ukraine or even other social catastrophes of the twentieth century.

It has taken decades for the Holodomor to gain recognition as a legitimate subject of research. As Holodomor Studies continues to grow, the range of themes, approaches, and theories will continue to expand. Historians will no doubt discover fresh meanings and different patterns that will link the study of the Holodomor across boundaries to other scholarly problems and fields in new and interesting ways. The "decentring" of history is already underway and undoubtedly represents the future for Holodomor Studies.

\section{Works Cited}

Akunin, O. S. Pivdennoukrains'ke selianstvo v kintsi 20-kh - pershii polovyni 30-kh rokiv XX st.: sotsial'no-ekonomichne stanovyshche. Dnipropetrovsk: Dnipropetrovs'kyi natsional'nyi universytet im. O. Honchara, 2009. Print.

Ambos, Kai. "What does 'Intent To Destroy' in Genocide Mean?" International Review of the Red Cross 91.876 (2009): 833-58. Print.

\footnotetext{
${ }^{34}$ One of the signs of the persistence and influence of this Cossack culture are the so-called "Cossack crosses," stone memorials, found in parts of central Ukraine. They continued to be erected for centuries until the 1930s (Zymovets').
} 
Andriewsky, Olga, and Natalie Pringle. "Social Science Meets Memory: The Harvard Project on the Soviet Social System as a Source on the Holodomor." Holodomor 1932-1933 rokiv v Ukraini: istoriia i pam'iat'. Kyiv. 21 Nov. 2013. Unpublished conference paper.

Antonovych, Myroslava. "Holodomor 1932-1933 rokiv v Ukraini v konteksti radians'koho henotsydu proty ukrains'koi natsii." Holodomor 1932-1933 rokiv v Ukraini iak zlochyn henotsydu zhidno z mizhnarodnym pravom. Ed. Volodomyr Vasylenko and Myroslava Antonovych. Kyiv: Kyievo-Mohylians'ka akademiia, 2012. 74-94. Print.

Bachyns'ka, Olena. "Malorosiis'ki kozaky" XIX st.: sotsio-demohrafichna kharakterystyka ta terytorial'ne rozselennia." Istoryko-heohrafichni doslidzhennia v Ukraini 12 (2012): 1526. Print.

Bakhtin, Anatolii M. Kolektyvizatsiia sil's'koho hospodarstva i holod na terytorii pivdnia Ukrainy (1929-1933 rr.). Kyiv: Kyievo-Mohylians'ka akademiia, 2006. Print.

Boriak, H. V., and H. V. Papakin. "Holodomor v Ukraini 1932-1933: Reiester arkhivnykh dokumentiv, opublikovanykh u 1990-2007 rr." Natsional'na Knyha pam'iati zhertv Holodomoru 1932-1933 rr. v Ukraini. Kyiv: Vyd-vo im. O. Telihy, 2008. 421-532. Print.

Boriak, Tetiana. "Prodovol'cha dopomoha Kremlia iak instrument Holodomoru v Ukraini." Zlochyny totalitarnykh rezhymiv $v$ Ukraini: Naukovyi ta osvitnii pohliad. Kyiv: NIOD \& Ukrains'kyi tsentr vyvchennia istorii Holokostu, 2012. 10-33. Print.

Boryk, Jennifer. "Memory Politics: The Use of the Holodomor as a Political and Nationalistic Tool in Ukraine." MA thesis. Central European University, 2011. Print.

Borysenko, Valentyna. "Holodomor 1932-1933 rokiv u misti Kyievi ta peredmisti." Etnichna istoriia narodiv Evropy 25 (2008): 5-14. Print.

Botushans'ka, O. F., ed. Holodomor v Ukraini 1932-1933 rr.: bibliohrafichnyi pokazhchyk. 2 vols. Odesa and Lviv: Odes'ka derzhavna naukova biblioteka imeni M. Hor'koho; Instytut istorii Ukrainy NAN Ukrainy; Fundatsiia ukrainoznavchykh studii Avstralii, Vyd-vo M. P. Kots', 2001. Print.

Carynnyk, Marco. "Blind Eye to Murder: Britain, the United States and the Ukrainian Famine of 1933." Famine in Ukraine 1932-1933. Ed. Roman Serbyn and Bohdan Krawchenko. Edmonton: Canadian Institute of Ukrainian Studies, 1986. 109-38. Print.

---. "Making the News Fit to Print: Walter Duranty, the New York Times and the Ukrainian Famine of 1933." Famine in Ukraine 1932-1933. Eds. Roman Serbyn and Bohdan Krawchenko. Edmonton: Canadian Institute of Ukrainian Studies, 1986. 67-95. Print.

"Communist Ukrainian Institute Head Denies Famine Was Deliberate." Radio Free Europe/Radio Liberty. 29 July 2010. Web. 24 Oct. 2014.

Conquest, Robert. The Harvest of Sorrow: Soviet Collectivization and the Terror-Famine. New York: Oxford University Press, 1986. Print.

Danilov, Viktor Petrovich, and Lynne Viola. Tragediia sovetskoi derevni: kollektivizatsiia i raskulachivanie: dokumenty i materialy v 5 tomakh, 1927-1939. 5 Vols. Moscow: Rossiiskaia polit. entsiklopediia, 2001. Print.

Danylenko, Viktor, and Petro Bondarchuk. “Ukrainizatsiia' i holod 1932-1933 rokiv v Ukraini." Problemy istorii Ukrainy: fakty, sudzhennia, poshuky 18 (2008): 327-35. Print.

Davies, R.W., O. V. Khlevniuk, and E. A. Rees, eds. The Stalin-Kaganovich Correspondence, 1931-36. New Haven: Yale University Press, 2003. Print.

Dolot, Miron. Execution by Hunger: The Hidden Holocaust. 1st ed. New York: W.W. Norton, 1985. Print. 
---. Who Killed Them and Why?: In Remembrance of Those Killed in the Famine of 19321933 in Ukraine. Cambridge, MA: Harvard University Ukrainian Studies Fund, 1984. Print.

Doroshko, Mykola. "Kerivna verstva USRR v umovakh Holodomoru 1932-1933 rr." Problemy istorii Ukrainy: fakty, sudzhennia, poshuky 18 (2008): 75-91. Print.

---. "Partiini chystky iak zasib likvidatsii opozytsii v KP(b)U v 20-30-ti roky XX st." Henotsyd ukrains'koho narodu: istorychna pam"iat' ta polityko-pravova otsinka. Kyiv: Vyd-vo M. P. Kots', 2003. 136-48. Print.

"Dvi tretyny meshkantsiv krainy vvazhaiut' Holodomor henotsydom ukrains'koho narodu-opytuvannia." Korrespondent 11 Nov. 2013. Web. 24 Oct. 2014.

Ellman, Michael. "Stalin and the Soviet Famine of 1932-33 Revisited." Europe-Asia Studies 59.4 (2007): 663-93. Print.

Foucault, Michel. Security, Territory, Population: Lectures at the Collège De France, 19771978. Ed. Michel Senellart, François Ewald and Alessandro Fontana. New York: Picador/Palgrave Macmillan, 2009. Print.

Graziosi, Andrea. The Great Soviet Peasant War: Bolsheviks and Peasants, 1917-1933. Harvard Papers in Ukrainian Studies. Cambridge, MA: Ukrainian Research Institute, Harvard University, 1996. Print.

Graziosi, Andrea. "The Soviet 1931-1933 Famines and the Ukrainian Holodomor: Is a New Interpretation Possible, and What Would Its Consequences Be?" Harvard Ukrainian Studies 27.1-4 (2004-2005): 97-115. Print.

Greenawalt, Alexander K. A. "Rethinking Genocidal Intent. The Case for a Knowledge-Based Interpretation." Columbia Law Review 99 (1999): 2259-94. Print.

Hanzha, Oksana I. Ukrains'ke selianstvo v period stanovlennia totalitarnoho rezhemu (19171927 rr.). Kyiv: Instytut istorii Ukrainy, NAN Ukrainy, 2000. Print.

Harvard Ukrainian Research Institute. "MAPA. Digital Atlas of Ukraine." 2013. Web. 24 Oct. 2014. <http://gis.huri.harvard.edu/>

Himka, John-Paul. “Encumbered Memory: The Ukrainian Famine of 1932-33.” Kritika 14.2 (2013): 411-36. Print.

---. "Problems with the Category of Genocide and With Classifying the Ukrainian Famine of 1932-33 as a Genocide." Holodomor 1932-1933 rokiv v Ukraini: prychyny, demohrafichni naslidky, pravova otsinka. Kyiv: Kyiv-Mohyla Academy, 2009. 413-20. Print.

Holodomor 1932-1933. Web. 24 Oct. 2014. <http://holodomor33.org.ua>

Holodomor: Ukrainian Genocide in the Early 1930s. Kyiv: Ukrainian Institute of National Memory, 2008. Print.

Hrynevych, Liudmyla. Khronika kolektyvizatsii ta Holodomoru v Ukraini 1927-1933. Vol. 1, Books 1-3. Kyiv: Krytyka, 2008-2012. Print.

---. 'Stalins'ka 'revoliutsiia zhory' ta holod 1933 r. iak faktory polityzatsii ukrains'koi spil'noty." Ukrains'kyi istorychnyi zhurnal 5 (2003): 50-64. Print.

---. "Tsina stalins'koi 'revoliutsii zhory': ukrains'ke selianstvo v ochikuvanni na viinu." Problemy istorii Ukrainy: fakty, sudzhennia, poshuky 16.1 (2007): 287-306. Print.

Iefimenko, H. H. "Zmina vektoriv u natsional'nii politytsi Moskvy v holodomornyi 1933 r." Ukrains'kyi istorychnyi zhurnal 5 (2003): 25-50. Print.

---. "Zminy v natsional'nii politytsi TsK VKP(b) v Ukraini (1932-1938)." Ukrains'kyi istorychnyi zhurnal 2 (2000): 82-93. Print. 
Irvin-Erickson, Douglas. "Genocide, the 'Family of Mind' and the Romantic Signature of Raphael Lemkin." Journal of Genocide Research 15.3 (2013): 273-96. Print.

Ivnitskii, N. A. Golod 1932-1933 godov v SSSR. Moscow: Sobraniie, 2009. Print.

---. Kollektivizatsiia i raskulachivanie (nachala 30-kh godov). Moscow: Magistr, 1996. Print.

“Iz Instituta Natspam'iati uvolen 'zashchitnik genotsida'." LB.ua. 16 Sept. 2010. Web. 24 Oct. 2014.

Kas'ianov, Heorhii. Danse macabre: Holod 1932-1933 rokiv u politytsi, masovii svidomosti ta istoriohrafii (1980-ti - pochatok 2000-kh). Kyiv: Nash chas, 2010. Print.

---. "Holodomor and the Politics of Memory in Ukraine after Independence." Holodomor and Gorta Mór: Histories, Memories and Representations of Famine in Ukraine and Ireland. Ed. Lindsay Janssen, Vincent Comerford and Christian Noack. London, New York and Delhi: Anthem Press, 2012. 167-88. Print.

Kasianov, Georgiy. "Revisiting the Great Famine of 1932-1933: Politics of Memory and Public Consciousness (Ukraine after 1991)." Past in the Making: Historical Revisionism and Central Europe after 1989. Ed. Michal Kopeček. Budapest and New York: Central European University Press, 2008. 197-219. Print.

"Kil'kist' ukraintsiv, iaki vvazhaiiut' Holodomor henotsydom z kozhnym rokom zrostaie." Tyzhden'11 Nov. 2013. Web. 24 Oct. 2014.

Kis, Oksana. “Defying Death: Women's Experience of the Holodomor, 1932-1933. Aspasia 7 (2013). Web. 1 June 2014.

Klid, Bohdan, and Alexander J. Motyl, eds. The Holodomor Reader: A Sourcebook on the Famine of 1932-1933 in Ukraine. Toronto: CIUS Press, 2012. Print.

Kocherha, Ol'ha. "Movoznavchi represii 1933 roku." Ji 35 (2004). Web. 24 Oct. 2014.

Kravchuk, Leonid. "My ne maiemo prava znekhtuvaty urokamy mynuloho." Holodomor 1932-1933 rr. v Ukraini: prychyny ta naslidky. Ed. Stanislav Kul'chyts'kyi. Kyiv: Instytut istorii, NAN Ukrainy, 1995. 8-11. Print.

Kul'chyts'kyi, Stanislav. "Dzheims Meis - liudyna i vchenyi." Problemy istorii Ukrainy: fakty, sudzhennia, poshuky 18 (2008): 9-28. Print.

---. “Holodomor 1932-33 rr.: Mekhanizm stalins'koho teroru." Ukrains'kyi istorychnyi zhurnal 4 (2007): 4-28. Print.

---. "Opir selianstva sutsil'nii kolektyvizatsii." Holod 1932-1933 rokiv v Ukraini: Prychyny ta naslidky. Ed. V. A. Smolii. Kyiv: Naukova dumka, 2003. Print.

---. Pochemu on nas unichtozhal? Stalin i ukrainskii golodomor. Kyiv: Ukrainskaia pressgruppa, 2007. Print.

---. Ukrains'kyi Holodomor v konteksti polityky Kremlia pochatku 1930-x rr. Kyiv: NAN Ukrainy, Instytut istorii Ukrainy, 2014. Print.

---. 'Vynyshchuval'ni aktsii': pam"iat' dvokh narodiv. Holodomory v Ukraini ta Kazakhstani u porivnial'nomu analizi (do pidsumkiv naukovoho seminaru v Kazakhstani)." Den' 30 May 2013. Web. 24 Oct. 2014.

Kulchytsky, Stanislav. "Why did Stalin exterminate the Ukrainians?" The Day (Den') 25 Oct. 2005; 1 Nov. 2005; 8 Nov. 2005; 15 Nov. 2005; 22 Nov. 2005. Web. 24 Oct. 2014.

Kuromiya, Hiroaki. Freedom and Terror in the Donbas: A Ukrainian-Russian Borderland, 1870s-1990s. Cambridge and New York: Cambridge University Press, 1998. Print.

---. The Voices of the Dead: Stalin's Great Terror in the 1930s. New Haven: Yale University Press, 2007. Print. 
Lemkin, Raphael. Axis Rule in Occupied Europe: Laws of Occupation, Analysis of Government, Proposals for Redress. Washington: Carnegie Endowment for International Peace, Division of International Law, 1944. Print.

---. "Soviet Genocide in the Ukraine." Holodomor: Reflections on the Great Famine of 19321933 in Soviet Ukraine. Kingston: Kashtan Press, 2009. 235-42. Print.

Levchuk, N. M. "Raionna dyferentsiatsiia vtrat naselennia Ukrainy unaslidok holodu v 1933 rotsi." Holod v Ukraini u pershii polovyni XX stolittia: Prychyny ta naslidky (1921-23, 1932-33, 1946-1947). Kyiv: Instytut istorii Ukrainy NAN Ukrainy, 2013. 257-64. Print.

Libanova, Ella. "Katastrofa ta ii vidlunnia: Otsinka demohrafichnykh vtrat Ukrainy vnaslidok Holodomoru 1932-33 rokiv." Suchasnist' 11 (2008): 22-29. Print.

---. "Otsinka demohrafichnykh vtrat Ukrainy vnaslidok Holodomoru 1932-1933 rokiv." Holodomor 1932-1933 rokiv v Ukraini: prychyny, demohrafichni naslidky, pravova otsinka. Kyiv: Kyievo-Mohylians'ka akademiia, 2009. 266-77. Print.

Lih, Lars T., Oleg V. Naumov, and Oleg V. Khlevniuk, eds. Stalin's Letters to Molotov. New Haven: Yale University Press, 1995. Print.

Maniak, Volodymyr A., and Lidiia B. Kovalenko, eds. "33-i Holod": Narodna Knyha Memorial. Kyiv: Radians'kyi pys'mennyk, 1991. Print.

Martin, Terry. The Affirmative Action Empire: Nations and Nationalism in the Soviet Union, 1923-1939. Ithaca: Cornell University Press, 2001. Print.

Matvieiev, A. Iu. Kolektyvizatsiia i rozkurkulennia selian Podillia ta Pivdenno-Skhidnoi Volyni (druha polovyna 20-kh - seredyna 30-kh rokiv XX st.). Chernivtsi: Chernivets'kyi natsional'nyi universytet im. Iu. Fed'kovycha, 2009. Print.

McDonnell, Michael A., and A. Dirk Moses. "Raphael Lemkin as Historian of Genocide in the Americas." Journal of Genocide Research 7.4 (December 2005): 501-29. Print.

Motyl, Alexander J. "Deleting the Holodomor: Ukraine Unmakes Itself." World Affairs Journal. September/October 2010. Web. 24 Oct. 2014.

---. “Ukraine's Orange Blues: Genocide's Definition Revisited." World Affairs Journal. 19 Oct. 2012. Web. 24 Oct. 2014.

---. "Ukraine's Orange Blues: Was the Holodomor Genocide?" World Affairs Journal. 8 Apr. 2011. Web. 24 Oct. 2014.

---. Ukraine's Orange Blues: Yanukovych and Stalin's Genocide." World Affairs Journal. 29 Nov. 2012. Web. 24 Oct. 2014.

Natsional'na Knyha pam"iati zhertv Holodomoru 1932-1933 rr. v Ukraini. 19 vols. Kyiv: Ukrains'kyi instytut natsionalnoi pam"iati, 2008. Print.

Noll, Vil'iam. Transformatsiia hromadians'koho suspil'stva. Usna istoriia selians'koi kul'tury 1920-30 rokiv. Kyiv: Rodovid, 1999. Print.

Odynoka, L. P., L. F. Prykhod'ko, and R. V. Romanovs'kyi, eds. Holodomory v Ukraini 1921-23, 1932-1933, 1946-1947. Kyiv: Derzhavnyi komitet arkhiviv Ukrainy, Ukrains'kyi naukovo-doslidnyi instytut arkhivnoi spravy ta dokumentoznavstva, 2005. Print.

Papakin, H. "Blacklists' as a Tool of the Soviet Genocide in Ukraine." Holodomor Studies 1.1 (2009): 55-75. Print.

Papakin, Heorhii. "Arkhivni dokumenty pro 'Chorni doshky' iak znariaddia radians'koho henotsydu v Ukraini v 1932-1933 rokakh." Arkhivy Ukrainy 261.3-4 (2008): 14-28. Print.

---. 'Chorna doshka': antyselians'ki represii (1932-33). Kyiv: Instytut istorii Ukrainy, 2013. Print. 
---. '“Chorni doshky' Holodomoru-ekonomichnyi metod znyshchennia hromadian URSR." Ukrains'ka pravda 27 November 2010. Web. 24 Oct. 2014.

---. “'Chorni doshky' iak oblychchia Holodomoru.” Web. 24 Oct. 2014. <http://histans.com/LiberUA/Papakin_Bl_Desk/Papakin_Bl_Desk.pdf>

---. '“Chorni doshky' iak znariaddia radians'koho henotsydu v Ukraini v 1932-1933 rokakh." Holodomor 1932-1933 rokiv v Ukraini: prychyny, demohrafichni naslidky, pravova otsinka. Ukrains'kyi instytut natsional'noi pam'iati. Kyiv: Akademiia, 2009. 5987. Print.

---. “Neopublikovani stalins'ki dyrektyvy lystopada 1932 r.: Kreml' i 'chorna doshka'." Ukrains'kyi istorychnyi zhurnal 6 (2013): 45-57. Print.

Papakin, Heorhii, and Olena Lisniak. "Dodatok: Zahal'nyi spysok naselenykh punktiv, zanesenykh na 'chornu doshku' u 1932-1933 rr." Institut Istorii Ukrainy, Natsional'na Akademii Nauk Ukrainy (2010). Web. 24 Oct. 2014. <http://www.history.org.ua/ index.php?litera\&id=9033\&navStart=3>

Petrenko, Ie. D. “Ukrains'ke kozatstvo v ostanii chverti XVIII - na pochatku XX st." Problemy istorii Ukrainy XIX - pochatku XX st. 15 (2008): 129-33. Print.

Pidhainy, Semen, ed. The Black Deeds of the Kremlin: A White Book. Vol. I. Toronto: Ukrainian Association of Victims of Russian Communist Terror, 1953; Vol. II. Detroit: Democratic Organization of Ukrainians Formerly Persecuted by the Soviet Regime, 1955. Print.

"Polovyna zhyteliv skhidnoi Ukrainy zaperechuiut', shcho Holodomor buv henotsydom." Dzerkalo tyzhnia 21 November 2012. Web. 24 Oct. 2014.

Postyshev, P. “Borot'ba KP(b)U za zdiisnennia lenins'koi natsional'noi polityky na Ukraini." Chervonyi shliakh 2-3 (1934): 165-76. Print.

Pshenychnyi, Taras Iu. Holod 1932-1933 rokiv v Ukraini (na materialakh pivdennoskhidnykh oblastei). Pereiaslav-Khmelnyts'kyi: Pereiaslav-Khmel'nyts'kyi derzh. pedahohichnyi universytet im. Hryhoriia Skovorody, 2008. Print.

Pyrih, R. Ia., ed. Holodomor. 1932-1933 v Ukraini: dokumenty i materialy. Kyiv: KyievoMohylians'ka Akademiia, 2007. Print.

Rudnyts'kyi, O. P., and A. B. Savchuk. "Holod 1932-33 rr. v Ukraini u demohrafichnomu vymiri." Holod v Ukraini u pershii polovyni XX stolittia: Prychyny ta naslidky (1921-23, 1932-33, 1946-1947). Kyiv: Instytut istorii Ukrainy NAN Ukrainy, 2013. 281-88. Print.

Rudnytsky, O., et. al. "1932-33 Famine Losses in Ukraine within the Context of the Soviet Union." Famines in European Economic History: The Last Great European Famines Reconsidered. Ed. Declan Curran, Lubomyr Luciuk and Andrew Newby. London and New York: Routledge, forthcoming 2015. Print.

"SBU nazvala ostatochnu kil'kist' zhertv Holodomoru v Ukraini." TSN. 14 Jan. 2010. Web. 24 Oct. 2014.

Scott, James C. Seeing Like a State: How Certain Schemes to Improve the Human Condition Have Failed. Yale Agrarian Studies. New Haven, Conn.: Yale UP, 1998. Print.

Serbyn, Roman. "Is There a 'Smoking Gun' for the Holodomor?" UNIAN. 19 Nov. 2007. Web. 24 Oct. 2014.

---. “Osmyslennia Holodomoru v svitli konventsii OON pro genotsyd." Holodomor 19321933: prychyny, demohrafichni naslidyky, pravova otsinka. Kyiv: Kyievo-Mohylians'ka Akademiia, 2009. 400-412. Print. 
---. "Raphael Lemkin, the UN Convention of 1948, and the Case for the Ukrainian Genocide." Danyliw Research Seminar in Contemporary Ukrainian Studies. Yumpu. 2008. Web. 24 Oct. 2014.

---. "The Ukrainian Famine of 1932-1933 as Genocide in the Light of the UN Convention of 1948." The Ukrainian Quarterly 62 (2): 181-94. Print.

Serbyn, Roman, and Bohdan Krawchenko, eds. Famine in Ukraine 1932-1933. Edmonton: Canadian Institute of Ukrainian Studies, 1986. Print.

Serbyn, Roman, and Olesia Stasiuk, eds. Rafael' Lemkin: Riadians'kyi henotsyd v Ukraini (stattia 28 movamy). Kyiv: Maisternia knyhy, 2009. Print.

Serput'ko, Alla Iuriivna. "Suchasna ukrainsk'ka ta rosiis'ka istoriohrafiia prychyn ta naslidkiv holodomoru v URSR 1932-1933 rokiv." Kand. ist. nauk. Cherkasy. Natsional'nyi universytet im. B. Khmel'nyts'koho, 2009. Print.

Shevchuk, P. Ie. "Metodychni pidkhody do obchyslennia demohrafichnykh utrat pid chas holodu 1932-33 rr." Holod v Ukraini u pershii polovyni XX stolittia: Prychyny ta naslidky (1921-23, 1932-33, 1946-1947). Kyiv: Instytut istorii Ukrainy NAN Ukrainy, 2013. 28993. Print.

Soldatenko, V. F. [Valerii F.] "Prychyny ta demohrafichni naslidky holodu 1932-1933 rr.: dva pohliady na odne iavyshche (do 79-oi richnytsi Holodomoru 1932-33 rokiv)." Ukrains'kyi Instytut Natsional'noi pam'iati (2012). Web. 5 Sept. 2013. <http: //histans.com/LiberUA/PrNasl/PrNasl.pdf>

---. "Trahediia trydtsiat' tret'oho: notatky na istoriohrafichnomu zrizi." Natsional'na ta istorychna pam"iat': zbirnyk naukovykh prats'. Kyiv: Ukrains'kyi instytut natsional'noi pam"iati, 2012. 3-92. Print.

---. "Ukrains'kyi instytut national'noi pam"iati s'ohodni." Ukrains'kyi instytut natsional'noi pam"iati (2014). Web. 24 Oct. 2014. <http://www.memory.gov.ua/news/ukrainskiiinstitut-natsionalnoi-pam-yati-sogodni>

Solovei, D. F. [Dmytro F.] Skazaty pravdu: try pratsi pro holodomor 1932-1933 rokiv. Kyiv and Poltava: [n.p.], 2005. Print.

Solvey, Dmytro. The Golgotha of Ukraine. New York: Ukrainian Congress Committee of America, 1953. Print.

Starovoitov, Mykola M., and Volodymyr V. Mykhailychenko, eds. Holodomor na Luhanshchyni 1932-1933 rr.: Naukovo-dokumental'ne vydannia. Kyiv: Stylos, 2008. Print.

Stasiuk, Olesia. "Deformatsiia narodnoi kul'tury v roky henotsydu." Problemy istorii Ukrainy: fakty, sudzhennia, poshuky 18 (2008): 349-61. Print.

---. Henotsyd ukraintsiv: deformatsiia narodnoi kul'tury. Kyiv: Stylos, 2008. Print.

Sukhomlin, Nikolai. "Ukraina vtratyla vid holodomoru ponad 10 mil'ioniv osib." KhaiVei 23 December 2009. Web. 24 Oct. 2014.

Suslyk, L. R. Sumni spohady: 1933 rik na Poltavshchyni. Munich?: [n.p.], 1951. Print.

Sysyn, Frank. "The Ukrainian Famine of 1932-3: The Role of the Ukrainian Diaspora in Research and Public Discussion." Studies in Comparative Genocide. Ed. Levron Chorbajian and George Shirinian. New York-London: Palgrave Macmillan, 1999. 182-215. Print.

"Ukaz Prezydenta Ukrainy № 1310/98 Pro vstanovlennia Dnia pam"iati zhertv holodomoriv ta politychnyk represii." president.gov.ua. 26 Nov. 1998. Web. 24 Oct. 2014. 
"Ukaz Prezydenta Ukrainy No. 868/2006. Pro vidznachennia u 2006 rotsi Dnia pam"iati zhertv holodomoriv ta politychnykh represii." Verkhovna rada Ukrainy. 12 Oct. 2006. Web. 24 Oct. 2014.

"Ukaz Prezydenta Ukrainy № 431/2007. Pro zakhody u zv"iazku z 70-my rokovynamy Velykoho teroru - masovykh politychnykh represii 1937 - 1938 rokiv." president.gov.ua. 21 May 2007. Web. 24 Oct. 2014.

United States. Commission on the Ukraine Famine. Investigation of the Ukrainian Famine, 1932-1933: Report to Congress. Washington: U.S. G.P.O., 1988. Print.

Vallin, Jacques, et. al. "A New Estimate of Ukrainian population losses during the crises of the 1930s and 1940s. Population Studies 56 (2002): 249-64. Print.

Vallin, Jacques, et. al. "The Great Famine: Population Losses in Ukraine." Demohrafiia ta sotsial'na ekonomika 2.12 (2009): 3-11. Print.

Vasil'ev, Valerii. "Krest'ianskie vosstaniia na Ukraine: 1929-1930 gody." Svobodnaia mysl', 1992, no. 9: 70-78. Print.

Vasyl'iev, Valerii. "Evoliutsiia pohliadiv S. Kul'chyts'koho na holod 1932-1933 rr. u konteksti novitnykh tendentsii ukrains'koi istoriohrafii." Problemy istorii Ukrainy: fakty, sudzhennia, poshuky 16.1 (2007): 277-86. Print.

---. "Osoblyvosti vidnosyn Kremlia z kerivnytstvom riadians'koi Ukrainy pid chas Holodomoru 1932-1933 rr." Taking Measure of the Holodomor. New York: The Center for U.S.-Ukrainian Relations, 2013. Web. 24 Oct. 2014. <http: //usukrainianrelations.org/index.php?option=com_content\&task=view\&id=36 6\&Itemid=206>

---. "Porivnial'nyi analiz holodu ta Holodomoru: Vinnyts'ka oblast' (1920-1940-i rr.)." Istoriia Ukrainy: Malovidomi imena, podii, fakty 37 (2011): 111-35. Print.

---. "Selians'kyi opir kolektyvizatsii v Ukraini (1930-ti rr.)." Istoriia Ukrainy: Malovidomi imena, podii, fakty 31 (2005): 140-50. Print.

---. "Stosunky kerivnytstva SRSR ta USRR u 1932-1933 rokakh: 'Kryza doviry'." Holodomor 1932-1933 rokiv v Ukraini: prychyny, demohrafichni naslidky, pravova otsinka. Kyiv: Kyievo-Mohylians'ka akademiia, 2009. 87-108. Print.

Vasyl'iev, V., and Iu. Shapoval, eds. Komandyry velykoho holodu: Poizdka V. Molotova i L. Kaganovycha v Ukrainu ta na Pivnichnyi Kavkaz 1932-1933 rr. Kyiv: Geneza, 2001. Print.

Vasyl'iev, V., N. Vert, and S. Kokin, eds. Partiino-radians'ke kerivnytstvo USRR pid chas Holodomoru 1932-1933 rr.: Vozhdi. Pratsivnyky. Aktyvisty. Zbirnyk dokumentiv ta materialiv. Kyiv: Instytut istorii Ukrainy, 2013. Print.

Verstiuk, Vladyslav. “Ukrains'ko-rosiis'ki vidnosyny u sferi doslidzhennia pytan' Holodomoru 1932-1933 rr." Problemy istorii Ukrainy: fakty, sudzhennia, poshuky 18 (2008): 228-31. Print.

Veselova, Oleksandra. "Do problemy henotsydu ukrains'koho narodu holodom 1932-1933 rr." Problemy istorii Ukrainy: fakty, sudzhennia, poshuky 18 (2008): 101-12. Print.

---. "Holod iak viddzerkalennia represyvnoi polityky totalitarnoi imperii." Holodomory v Ukraini, 1921-1923, 1932-1933, 1946-1947: Zlochyny proty narodu. Ed. O. Veselova, V. I. Marochko, and O. M. Movchan. Kyiv and New York: Vydavnytstvo M.P. Kots', 2000. 188-212. Print. 
---. "Pam"iatni znaky i pam"iatnyky zhertvam Holodu-henotsydu 1932-1933 v Ukraini." Problemy istorii Ukrainy: fakty, sudzhennia, poshuky 13 (2005): 43441. Print.

---. "Svidchennia ochevydtsiv holodu-henotsydu 1932-1933 rokiv v Ukraini iak dzherelo vyvchennia ioho prychyn i naslidkiv." Holodomor 1932-1933 rokiv v Ukraini: prychyny, demohrafichni naslidky, pravova otsinka. Kyiv: KyievoMohylians'ka akademiia, 2009. 189-210. Print.

Veselova, O., V. I. Marochko, and O. M. Movchan, eds. Holodomory v Ukraini, 19211923, 1932-1933, 1946-1947: Zlochyny proty narodu. Kyiv and New York: Vydavnytstvo M.P. Kots', 2000. Print.

Viedienieiev, D. V., and D. V. Budkov. Zaruchnytsia hlobal'noho protystoiannia: Trahediia Velykoho Holodu 1932-1933 rr. v Ukraini v konteksti "kholodnoi viiny" (1945-1991 rr.). Kyiv: Dorado-Druk, 2013. Print.

Viola, Lynne. Peasant Rebels Under Stalin: Collectivization and the Culture of Peasant Resistance. New York: Oxford University Press, 1996. Print.

"Vitse-prem"ier ministr Ukrainy Oleskandr Sych predstavyv kolektyvu Ukrains'koho instytutu natsional'noi pam"iati novoho dyrektora - Volodymyra V'iatrovycha." Ukrains'kyi instytut natsional'noi pam"iati. 27 March 2014. Web. 14 Apr. 2014.

Volovyna [Wolowyna], Oleh. "Pomisiachnyi rozpodil demohrafichnykh vtrat vnaslidok holodu 1933 roku v Ukraini." Holod v Ukraini u pershii polovyni XX stolittia: prychyny ta naslidky (1921-23, 1932-33, 1946-1947). Kyiv: Instytut istorii Ukrainy NAN Ukrainy, 2013. 233-42. Print.

von Hagen, Mark. "Rethinking the Meaning of the Holodomor: 'Notes and Materials' toward a(n) (Anti) (Post) Colonial History of Ukraine." Taking Measure of the Holodomor. New York: The Center for U.S.-Ukrainian Relations, 2013. Web. 24 Oct. 2014. <http://usukrainianrelations.org/images/pdf/[HESSE 201] von Hagen-Rethinking the Meaning of the Holodomor.pdf $>$

Werth, Nicolas. "The Great Ukrainian Famine of 1932-33." Online Encyclopedia of Mass Violence 2008. Web. 24 Oct. 2014.

Wheatcroft, S. G. "Mapping Crude Death Rates in Ukraine in 1933 and Explaining the Raion Patterns." Holod v Ukraini u pershii polovyni XX stolittia: prychyny ta naslidky (1921-23, 1932-33, 1946-1947). Kyiv: Instytut istorii Ukrainy NAN Ukrainy, 2013. 219-25. Print.

Wolowyna, Oleh. "The Famine-Genocide of 1932-33: Estimation of Losses and Demographic Impact." The Holodomor Reader: A Sourcebook on the Famine of 1932-1933 in Ukraine. Ed. Bohdan Klid and Alexander J. Motyl. Toronto: CIUS Press, 2012. 59-64. Print.

---. "Holodomor Losses: Methodological Problems and Research Challenges." Holodomor 1932-1933 rokiv v Ukraini: prychyny, demohrafichni naslidky, pravova otsinka. Kyiv: Kyievo-Mohylians'ka akademiia, 2009. 278-92. Print.

"Yanukovych Reverses Ukraine's Position on Holodomor Famine." RIA Novosti. 27 April 2010. Web. 24 Oct. 2014.

“Zakon Ukrainy pro Holodomor 1932-1933 v Ukraini." Vidomosti Verkhovnoi Rady Ukrainy 50 (2006): 504. Print.

Zawada, Zenon "Wikileaks and Ukraine: Holodomor, Shady Business Deals and Gaddafi." The Ukrainian Weekly 5 December 2010: 1, 19. Print. 
Zymovets', Roman. "Kam"iani kozats'ki khresty ta sil's'ki tsvyntari Trakhtemyrivs'koho rehionu: malovidomi memorial'ni pam"iatky ukrains'koi istorii." Arkheolohiia Seredn'oi Naddniprianshchyny. 16 June 2013. Web. 24 Oct. 2014. 